Article

\title{
Regional Socioeconomic Changes Affecting Rural Area Livelihoods and Atlantic Forest Transitions
}

\author{
Ramon F. B. da Silva ${ }^{1, *(\mathbb{C})}$, Mateus Batistella ${ }^{1,2}$ and Emilio F. Moran ${ }^{3}$ (i) \\ 1 Center for Environmental Studies and Research, State University of Campinas, Campinas, SP 13083-867, \\ Brazil; mateus.batistella@embrapa.br \\ 2 EMBRAPA, Brazilian Agricultural Research Corporation, Campinas, SP 13083-886, Brazil \\ 3 Center for Global Change and Earth Observations, Michigan State University, East Lansing, MI 48823, USA; \\ moranef@msu.edu \\ * Correspondence: ramonbicudo@gmail.com; Tel.: +55-(19)-3521-7690
}

Received: 27 September 2018; Accepted: 20 October 2018; Published: 22 October 2018

check for updates

\begin{abstract}
Centuries of colonization of the Atlantic Forest biome in Brazil have led its native vegetation cover to be reduced to only $11.7 \%$. On the other hand, regional land changes have fostered natural forest regeneration, since the 1960s, in the region of Paraíba Valley. A fieldwork survey in rural properties was conducted in three municipalities ( $n=90$, thirty in each municipality), to assess how forest transition is affected by the region's socioeconomic development and biophysical dimensions of the landscape. To select the municipalities among thirty-four, we applied the modified Thompson Tau technique to detect outlier values for three selected variables: Natural forest cover, eucalyptus plantation cover, and municipal revenue. The outliers were dropped from consideration and the municipality with the maximum value for each variable was selected. Based on the survey and GIS analysis using land-cover maps, topography, and hydrology variables, we concluded that the diminished land-use pressure in the Paraíba Valley, a response to the regional economic development (e.g., increasing labor demand in urban areas pushing rural migration), resulted in the increase of the Atlantic forest cover. Interestingly enough, a counter-migration of people moving to rural areas as a newly valued amenity has the potential to reshape the rural landscape with positive outcomes to the Atlantic forest cover.
\end{abstract}

Keywords: rural property survey; thompson tau technique; land-use decisions; Atlantic forest transition

\section{Introduction}

Land-use and land-cover changes (LULCC) are significant drivers of global environmental changes [1,2] affecting soil carbon sequestration and emissions [3], water scarcity [4], climate changes [5], and social impacts such as human displacement [6]. Scientific research has analyzed how human decisions, institutions, and biophysical conditions interact and cause LULCC [7]. Human decisions shape how land is allocated according to specific purposes, not always guided by rational choices to maximize profits or to follow policies, and motivated by subjective and moral values $[8,9]$. Therefore, human decisions taken in rural properties are valuable to understand land-use change, to better support public policy and to envision future scenarios [10-12]. The use of surveys in rural areas is a widespread research method to access land-use decision-making, and to understand landowners' perceptions on ecosystem services [13], climate change impacts on agriculture [14,15], forest management strategies by smallholders [16], and socio-environmental pathways of agricultural changes [17-19].

Forest transition (FT) theory predicts that, after a period of deforestation, the declining stock of forest tends to stabilize leading to a period where the gains in forest area are greater than losses 
to deforestation [20]. To explain this transition process, many researchers worldwide have used national and global data, as well as regional and local analyses [7,21-27]. FT and LULCC are processes intrinsically connected through land allocation dynamics, rural and urban socioeconomic changes, urbanization, policies, and cultural aspects of human decisions. Therefore, accessing socioeconomic contexts and historical perceptions on regional land changes using the rural property as the unit of survey are key to understanding the effect of decision-making processes driving the resurgence of natural forest cover inside private lands.

\section{Atlantic Forest Cover through Time and the Focus on the Paraíba Valley Region}

Deforestation rates at the national level may overlook significant variations in the rates and patterns of forest changes in particular regions [28]. The Atlantic Forest reached very low levels of conservation after centuries of colonization and conversion of native vegetation into agricultural and pasture lands [29-31]. During the Brazilian period of industrialization between 1950 and 1980, certain portions of the country experienced huge fluxes of rural to urban migration. The Atlantic Forest biome encompasses the most economically developed and populated regions of Brazil, such as the São Paulo and Rio de Janeiro metropolitan areas. The biome extends through 17 States and is socially, culturally, and economically heterogeneous.

Forest cover data [32], has shown a decline in deforestation rates from 1985 to 2013, with different rates in each state-suggesting that the biome has not experienced these changes uniformly. The eastern portion of São Paulo state (i.e., the Paraíba Valley) had a significant rate of forest cover increase from 225 to 446 thousand hectares (ha) between 1962 and 2011 [33,34]. These results contrast with the general trend observed for the Atlantic Forest biome, one of no forest cover net gain [32,35].

The Paraíba Valley spreads between the states of São Paulo, Minas Gerais, and Rio de Janeiro, and the Paraíba watershed provides the bulk of the water supply to a population of approximately 10 million inhabitants [36], mainly in the states of Minas Gerais and Rio de Janeiro. In 2014, after the worst water crisis (drought) in São Paulo state in the last 80 years, the Federal Court of Justice accepted a request from São Paulo's governor to allow the state to also use this watershed to improve the water supply system for the São Paulo metropolitan region [37]. This chapter in the Paraíba Valley's history raises concern about the future of the watershed and the sustainability of its ecosystems services.

Less than $30 \%$ of the Paraíba Valley is under the regulation of conservation areas, which increases the role of private rural properties in the conservation of the Atlantic Forest remnants and their ecosystems services. This paper addresses the following questions: (a) How does the regional socioeconomic context of the Paraíba Valley affect land changes resulting in forest transitions? (b) Are biophysical variables and environmental policies related to this land change process within the rural properties? To address these questions, the study's methodological approach focused on the perspectives of landowners in the region, captured through surveys in rural properties.

\section{Materials and Methods}

\subsection{Sampling}

The Paraíba Valley within the São Paulo state comprises 34 municipalities and is classified by the State as the Water Resources Management Unit of Paraíba do Sul [36]. A set of variables (Table 1) was chosen to support the decision regarding which municipalities were to be sampled (Figure 1). The available knowledge about the region's land-use and land-cover dynamics [25,38,39] informed such choice.

Among the selected variables, a parametric outlier approach known as the modified Thompson tau technique was conducted. The modified Thompson tau technique is a method recommended in univariate datasets that consist of observations on only a single attribute. This method allows the discharge of one data point (i.e., outlier) at each time, ensuring a confident process of data mining and decisions about data points to be eliminated. An outlier is a data point significantly different 
from the remaining data, also referred to as anomalies. Therefore, an outlier contains information about abnormal characteristics of systems and entities, which impact the data generation process [40]. Considering the potential impact of the outlier to the survey results, the outlier was discharged to avoid bias in the analysis. Then, the municipality with the best performance (maximum value) for each variable was chosen.

Table 1. Variable dataset to select municipalities within the Paraíba Valley.

\begin{tabular}{|c|c|c|c|}
\hline & Brief Description of Variables & Mean & Std. Deviation \\
\hline Forest $\phi$ & $\begin{array}{l}\text { Mean variation of forest cover } \\
\text { percentage within the municipality } \\
\text { between } 1985 \text { and } 2011\end{array}$ & 22.69287 & 11.21238 \\
\hline Eucalyptus $\phi$ & $\begin{array}{l}\text { Percentage of increase in eucalyptus } \\
\text { plantation between } 1985 \text { and } 2011\end{array}$ & 3.17766 & 3.832879 \\
\hline Municipal revenue ${ }^{\theta}$ & $\begin{array}{l}\text { Mean value of the revenue (\$) per } \\
\text { municipality between } 1985 \text { and } 2011\end{array}$ & $89,891,625.22$ & $198,996,234.1$ \\
\hline
\end{tabular}

seade.gov.br/> In: "população e estatísticas vitais").
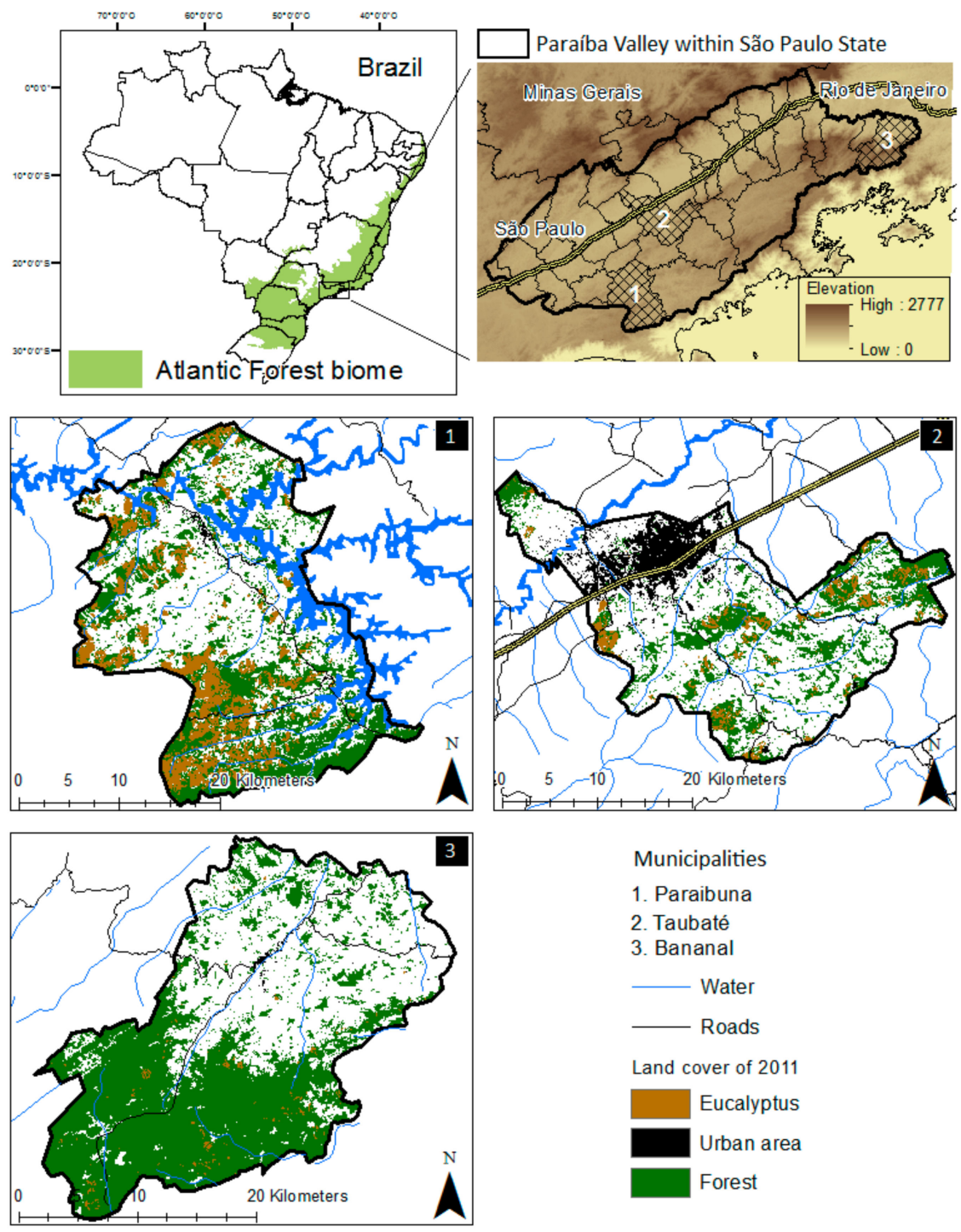

Land cover of 2011

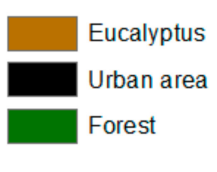

Figure 1. Selected municipalities studied in the Paraíba Valley, São Paulo state, Brazil. 
The modified Thompson value for 34 data points (municipalities) based on a significance level of 0.05 is $\tau=1.9174$. This value was used to determine the outlier by the equation: $\tau^{*} \delta$, where $\delta$ is the standard deviation value of each variable (Table 1 ). If the standard deviation for a specific municipality $\left(\delta_{1}\right)$ is $>\tau^{*} \delta$, the data point is rejected. If the standard deviation for a specific municipality $\left(\delta_{1}\right)$ is $\leq \tau^{*} \delta$, the data point is kept. Figure 2 presents the research methodological steps.

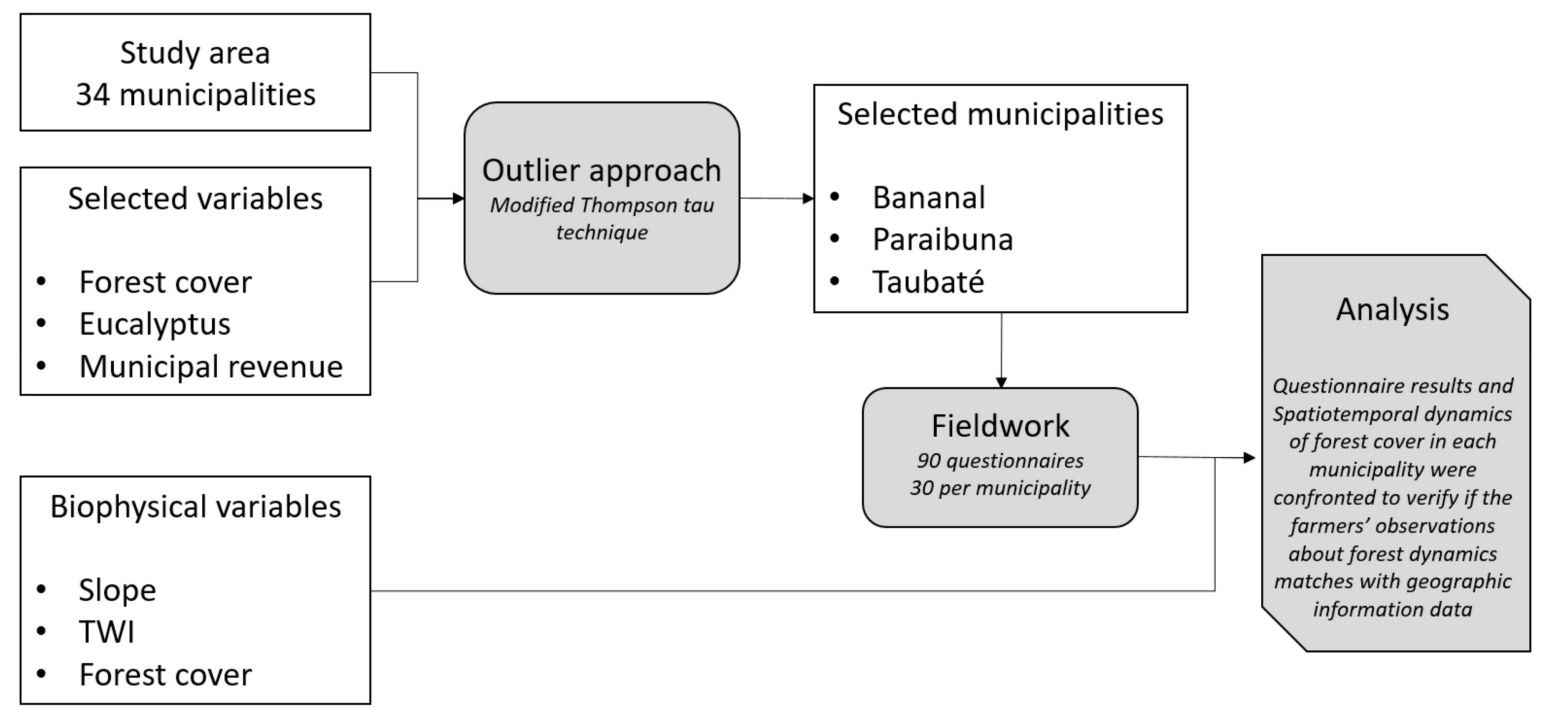

Figure 2. Methodological steps conducted to select study locations and to perform spatiotemporal analyses of land-use and land-cover changes with socioeconomic aspects of the Paraíba Valley.

\subsection{Rural Property Survey}

The survey was structured for any kind of rural property (by size and activity), addressing questions about economic (e.g., industrialization, urbanization), leisure (e.g., rural tourism, second home), social (e.g., labor, education level, age), and land-use trends (e.g., decrease of pasturelands), and how these trends interact with forest cover changes. The interviewer presented a summary of the research purpose to make sure that the interviewee had observed land changes within the rural property or in the landscape, with consequences to forest cover. If so, the survey was conducted within each municipality until completing the sample of thirty interviews. A total of ninety questionnaires was completed in the three municipalities.

To select the rural properties within the municipality, the research team used information from local public agencies, such as rural extension services and rural unions, land-use and land-cover maps to highlight forest cover areas, and road maps. Fieldwork was conducted between September and November 2014. The questionnaire was structured around seven broad questions with multiple choices and with the option "other" for the cases when the interviewee provided a different answer from those offered in the multiple choices. The overarching question behind the survey was: What is happening in the countryside to explain increases in forest cover area?

\subsection{Data and Analysis}

To improve understanding of land-use and socioeconomic dynamics in the Paraíba Valley countryside, two topographic independent variables were overlaid with the forest cover dependent variable: Topographic wetness index (TWI) and slope. These variables were derived from the Advanced Spaceborne Thermal Emission and Reflection Radiometer Global Digital Elevation Model, grid size of $30 \times 30 \mathrm{~m}$ (ASTER GDEM). The TWI characterizes the surface-water saturation zones and the water content in the soils [41], calculated by the equation:

$$
\operatorname{TWI}=\operatorname{Ln}(\alpha / \tan \beta)
$$


where $\alpha$ represents upslope area per unit contour length, and $\tan \beta$ stands for local down slope in a specific catchment area [42]. Given the hydrological concerns in the region and its importance to water supply, the TWI measures how the forest cover change is affected by water-saturated areas. These areas include core hydrologic processes in the watershed, such as runoff and soil saturation after rain, as well as the upstream contributing areas and streams network [43]. It is also a variable used to characterize biological processes, such as vegetation patterns and forest site quality [44]. Therefore, TWI identifies key information for agricultural and environmental watershed management, mainly regarding water conservation [41,42]. The slope parameter is an indicator of land-use constraints to irrigation, cattle ranching, and mechanization, which affect agricultural activities and land-use decisions. Steep slopes have several disadvantages for agricultural practices affecting the conditions for safe machinery operation [45], increasing irrigation costs (i.e., costs for pumping the water to higher elevations) [46], and boosting soil loss through erosion [47].

Based on the overlaid results from topographic and forest cover information, descriptive statistics was used to analyze the interviewees' answers to evaluate how land-cover change matches with land-use decisions and socioeconomic conditions in the countryside. In addition, population census and economic data (e.g., industrialization, municipal revenue) from the Brazilian Institute of Geography and Statistics (IBGE) were used to support the analysis.

\section{Results and Discussion}

\subsection{Rural Socioeconomic Characterization}

The outlier analysis identified three municipalities to be sampled (Table 2). Each municipality showed different levels of economic development, demographic trends (Figure 3), and geographic characteristics (Figure 1). However, they converge on several common conditions, such as hilly topography, low labor availability for agricultural jobs, and positive rates of forest cover increase.

Table 2. Selected municipalities to develop the rural household survey.

\begin{tabular}{lcccc}
\hline & Outlier & Threshold * & $\begin{array}{c}\text { Best Performance } \\
\text { (Maximum Value) }\end{array}$ & Municipality \\
\hline $\begin{array}{l}\text { Forest cover } \\
\text { Eucalyptus plantation }\end{array}$ & 29.5 & 21.4 & 21.2 & Bananal \\
Municipal revenue & $995,218,101.3$ & $381,555,379.2$ & $335,204,038.3$ & $\begin{array}{c}\text { Paraibuna } \\
\text { Taubaté }\end{array}$ \\
\hline * The threshold value is derived from the equation $\left(\tau^{*} \delta\right)$. The "Best performance" value corresponds to the elected \\
"Municipality" to be surveyed.
\end{tabular}

Table 3 presents the main agricultural and non-agricultural activities in the rural properties according to the survey.

Table 3. Description of the rural activities within the rural property.

\begin{tabular}{cccc}
\hline Rural Activities within the Property & Bananal & Paraibuna & Taubaté \\
\hline Dairy & 9 & 6 & 12 \\
Dairy and buffalo & 1 & -- & -- \\
Dairy and pig & 1 & -- & -- \\
Dairy and leisure & 1 & -- & -- \\
Dairy and horticulture & -- & 1 & 3 \\
Dairy and beef & -- & 2 & 3 \\
Dairy and eucalyptus & -- & 2 & -- \\
Dairy, beef and eucalyptus & -- & 1 & -- \\
Dairy, beef, eucalyptus and rural tourism & -- & 1 & -- \\
Dairy, rural tourism, leisure and sausage & -- & 1 & -- \\
\hline
\end{tabular}


Table 3. Cont.

\begin{tabular}{cccc}
\hline Rural Activities within the Property & Bananal & Paraibuna & Taubaté \\
\hline Dairy and cachaça & -- & 1 & -- \\
Dairy and rural tourism & -- & 1 & -- \\
Beef & 2 & 1 & -- \\
Beef and leisure & 2 & 1 & -- \\
Beef, leisure and cachaça * & 1 & -- & -- \\
Beef and cachaça & 1 & -- & -- \\
Leisure & 4 & 2 & 9 \\
Rural tourism & 2 & 2 & 1 \\
Rural tourism and leisure & 2 & & - \\
Eucalyptus plantation & -- & 2 & 1 \\
Horticulture & -- & 3 & 1 \\
Fruits & -- & 2 & -- \\
Agroforestry & -- & 1 & -- \\
Abandoned $\phi$ & 4 & -- & -- \\
\hline
\end{tabular}

* Traditional Brazilian liquor from sugar cane. ${ }^{\phi}$ No use according the interviewees-the landowners has no immediate plans to use the rural property to economic or social purposes.

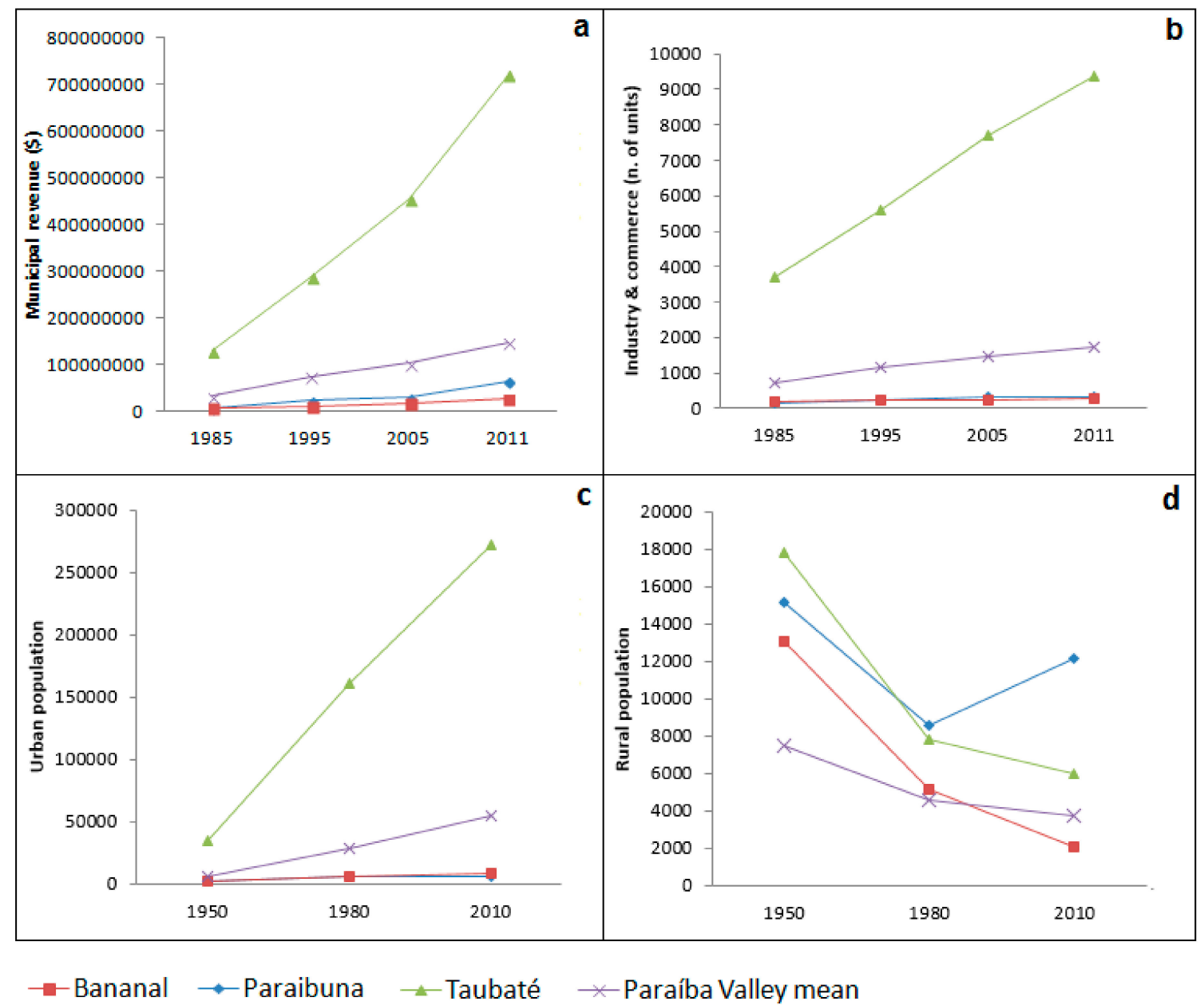

Figure 3. Selected socioeconomic data for the surveyed municipalities in the Paraíba Valley.

Cattle raising for beef and dairy production is the main rural activity but varies in quantity (Table 3) and management practices among the municipalities. Forty-six rural properties sampled have dairy production; thirty-six of them use management practices such as semi-confinement, rotation, and/or best adapted and more productive breeds of dairy cattle. At least one of these above-mentioned practices was adopted by $94 \%$ of the dairy producers in Taubaté, $96 \%$ in Paraibuna, and $25 \%$ in Bananal. 
The more productive dairy cattle breeds are not able to graze in steep slopes and this constrains farmers to adopt semi-confinement and intensified use of flat areas, predominantly along water streams.

The low contribution of Bananal, Paraibuna, and Taubaté to the State's agricultural revenue, about $0.1 \%$ in 2014, and the low contribution from agricultural activities for the municipality's GDP in the same year (6.94\% in Bananal, $4.3 \%$ in Paraibuna, and $0.47 \%$ in Taubaté) (SEADE ${ }^{1}$ ), reveals the marginal role of farming to local economic development. The farm size in the sample ranges from 5 to 1000 hectares with an average size of 125 hectares (Table 4). Rural economic policies favoring large-scale, highly productive, and highly intensified agribusinesses in Brazil [48-50] promoted the marginalization of less suitable agricultural areas, mainly those with severe mechanization constraints (i.e., steep slopes), as also noted in other studies [12,50,51].

Table 4. Distribution of farm size classes (in hectares) per municipality and the farmer's average age in each class.

\begin{tabular}{cccccccccc}
\hline Farm Size (ha) & \multicolumn{3}{c}{ Bananal } & \multicolumn{4}{c}{ Paraibuna } & \multicolumn{3}{c}{ Taubaté } \\
\hline & $\mathbf{n}$ & Area & Age & $\mathbf{n}{ }^{*}$ & Area & Age & n & Area & Age \\
\hline$<100$ & 18 & 825 & 56 & 20 & 981 & 54 & 18 & 630 & 60 \\
$100-300$ & 7 & 1240 & 69 & 9 & 1120 & 58 & 11 & 1860 & 61 \\
$300-500$ & 2 & 850 & 55 & 1 & 315 & 58 & -- & -- & - \\
$>500$ & 3 & 2650 & 68 & -- & -- & -- & 1 & 600 & 46 \\
\hline
\end{tabular}

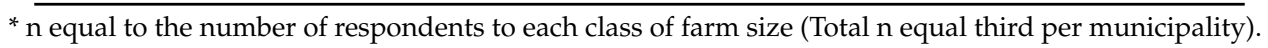

The aging of the rural population is a recent concern in Brazil. The average age of the sampled population was 59 years old, ranging from 23 to 82 years (Table 4). For economically developed regions, such as São Paulo state, younger farmers are less likely to be found than in less developed regions, such as Northern and Northeastern Brazil [52]. Urbanization may drive this trend as the new generations move to the cities, whilst older generations remain in the countryside. The Paraíba Valley's urban population increased $841 \%$ between 1950 and 2010, while in the municipalities of Bananal, Paraibuna, and Taubaté the population increased $270 \%, 212 \%$, and $674 \%$, respectively. Paraibuna is the only municipality showing positive rates of rural population growth, $42 \%$ from 1980 to 2010, contrasting with Taubaté $(-23 \%)$ and Bananal $(-59 \%)$, which lost populations [53].

Based on fieldwork information, these temporal variations in urban and rural populations are driven by regional economic development. Taubate attracted migration to its urban area due to industrialization and economic growth, as well as São José dos Campos, the major economic municipality in the region and the center of Brazil's aerospace industry. Even Bananal, the geographically most isolated municipality within the region, observed migration flows to Taubate and São José dos Campos during the second half of the twentieth century [54].

Among the sampled rural properties, $73 \%$ had other income sources than farming activities (26 rural properties in Bananal, 20 in Paraibuna, and 20 in Taubaté). Other sources of income may include part-time jobs or small businesses in urban areas, income from younger family members, and rural retirement pensions [55].

\subsection{Rural Livelihood Changes and Regional Land Transitions}

The environmental and socioeconomic changes in the Paraíba Valley during recent decades have affected landscape structure and composition $[25,39]$. The region's historical landscapes are mosaics of land-uses and forest patches embraced by two mountain ranges in a hilly topography [56]. Agricultural land-use abandonment has been the major land transition leading to FT [34].

1 SEADE-State System of Data analysis (Data serie: Informação dos Municípios Paulistas <http:/ / produtos.seade.gov.br/ produtos/imp/>). 
The survey included questions about socioeconomic variables potentially related to the FT process. Fifty-five out of the ninety interviewees associated FT with socioeconomic changes in the region. Among the choices related to socioeconomic variables, the low availability of labor for agricultural activities, the migration to urban areas motivated by expectations of better living conditions, and the loss of interest by young farmers to work in rural areas were predominant in the answers. In Taubaté, among the nineteen interviewees that associated FT to socioeconomic variables of the region, eighteen attributed it to the lack of rural labor. In Bananal, twenty-one interviewees pointed to urban attractions and rural conditions as FT drivers: Better living conditions in urban centers (nine answers) and higher offers of employment (eight answers), loss of the rural population's interest in rural activities (nine answers), and lack of rural labor (eleven answers). In Paraibuna, the lack of rural labor was unanimous among the fifteen interviewees, which associated FT with at least one socioeconomic variable.

The low availability of labor for agricultural activities is a generalized problem in the study region, as noted by farmers, unions, and rural public agencies [39]. Mechanization constraints, job opportunities outside rural areas, and better living conditions in urban centers were mentioned as causes for forest regeneration in the Valley.

The industrialization of the Paraíba Valley (since the 1960s) demanded a new demographic configuration during the transition from an agro-based economy to an industrial-based economy [57]. Therefore, São José dos Campos and its neighboring cities (e.g., Taubaté) attracted workers from many regions of the Valley and other parts of São Paulo State. According to informants from Bananal, entire rural neighborhoods migrated to São José dos Campos in the 1970s for jobs in the city.

The construction of State and Federal roads, oil and gas pipelines across the Valley, and other infrastructure projects, plus formal and informal job opportunities in urban areas have influenced workers to move to non-agricultural jobs. This situation is challenging the farmers' capacity of keeping employees on their farms. The work conditions in urban areas (e.g., industry, commerce) are pushing up the value of the rural wage and the demands for more labor benefits, driving famers to the edge of their financial limits. Thus, the income from land-use (e.g., dairy production) is not enough to make profits, making the agricultural enterprise unprofitable in some cases.

When the farmers lack reasonable economic conditions, the rural activity is not attractive and pushes new waves of rural workers to cities as they find it difficult even to keep the family labor in the rural area. Owing to the urbanization process and the development reached with the increase of the Brazilian middle class, fewer young workers are looking for job opportunities in rural areas in the most developed regions, such as São Paulo State [52].

\subsection{Biophisical Variables Driving Land Use Decisions and Affecting Regional Forest Cover Changes}

Figure 4 shows the forest cover changes (e.g., net gain) between 1985 and 2011 for the studied municipalities. Based on previous research [34], deforestation tends to diminish and concentrate over the first stages of successional forest (up to 10 years old), reducing pressure over older forest remnants regenerating before 1985, and for newer patches established until 1995. 


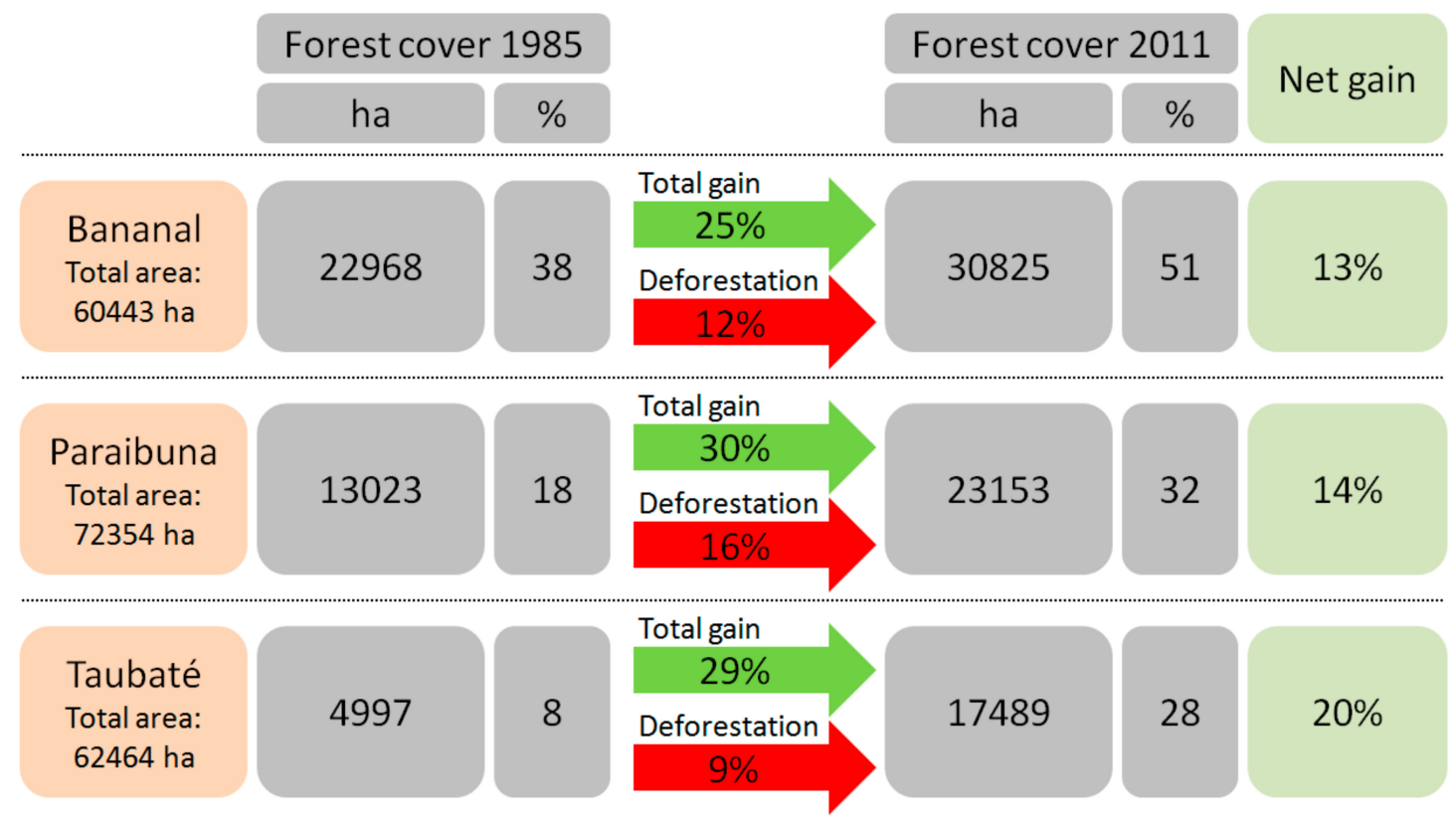

Figure 4. Forest cover changes between 1985 and 2011 in the municipalities of Bananal, Paraibuna, and Taubaté, Brazil (Forest cover data from Silva et al. [34]).

Since 1985 , forest net gain ranged from $13 \%$ to $20 \%$, revealing a process of FT occurring over former pasturelands and agricultural areas [34], which in turn, were established over deforested areas during the last two centuries $[30,58]$. This regional environmental transition process is leading to the return of native vegetation (in successional stages), mainly in areas less favorable to mechanized agriculture.

According to the System of Land-Use Capacity [59]—slope classes: 0-3\% (1), 3-6\% (2), 6-12\% (3), $12-20 \%(4), 20-40 \%$ (5), $>40 \%$ (6) - the majority of new forest areas occurred in classes 5 and 6 (Figure 5). These areas are less suitable for agriculture and livestock, but are suitable for restricted forestry operations, providing an outstanding opportunity for the restoration of ecosystem services and environmental sustainability.
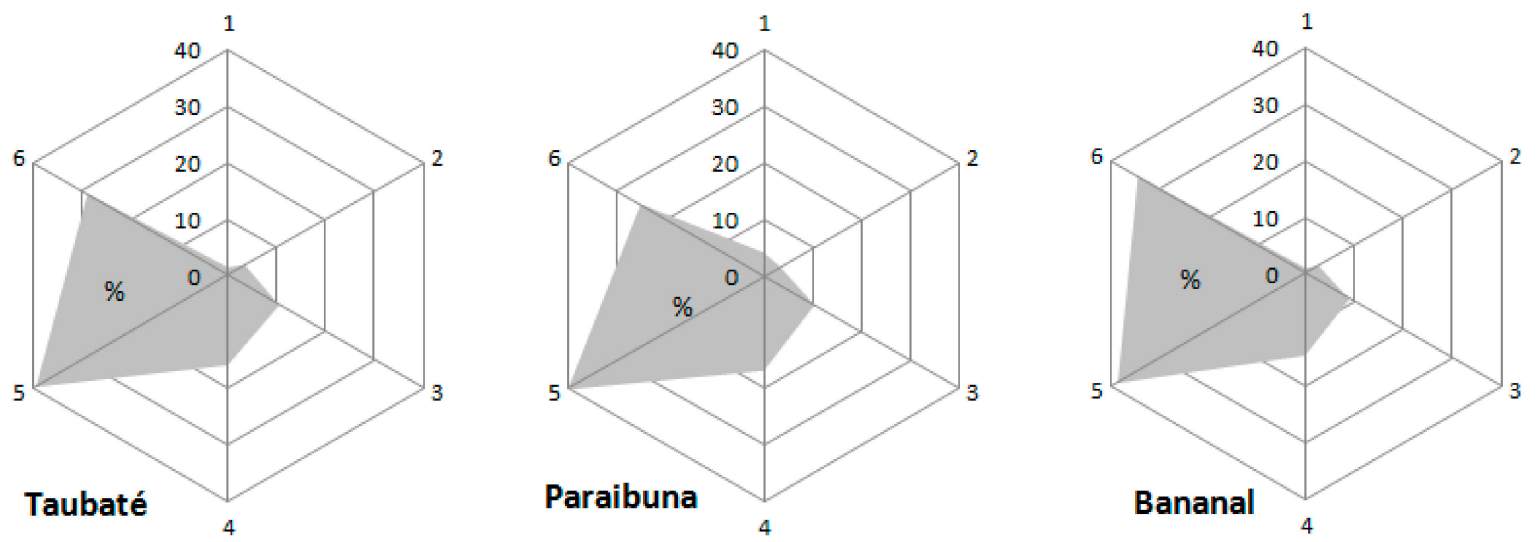

$\%$ of forest cover growth (1985-2011) - classes 1 to 6

Figure 5. Percentage of forest cover growth in the studied municipalities of the Paraíba Valley, Brazil.

Among the sixty-five rural properties with at least one agricultural activity, $81 \%$ of the respondents recognized the steep slopes as very significant constraints to land-use (Figure 6a). Therefore, these areas are more likely to be abandoned and replaced by successional forests through natural regeneration. These slopes have high opportunity costs, as they are typically unsuitable for cattle ranching and mechanized agriculture. 


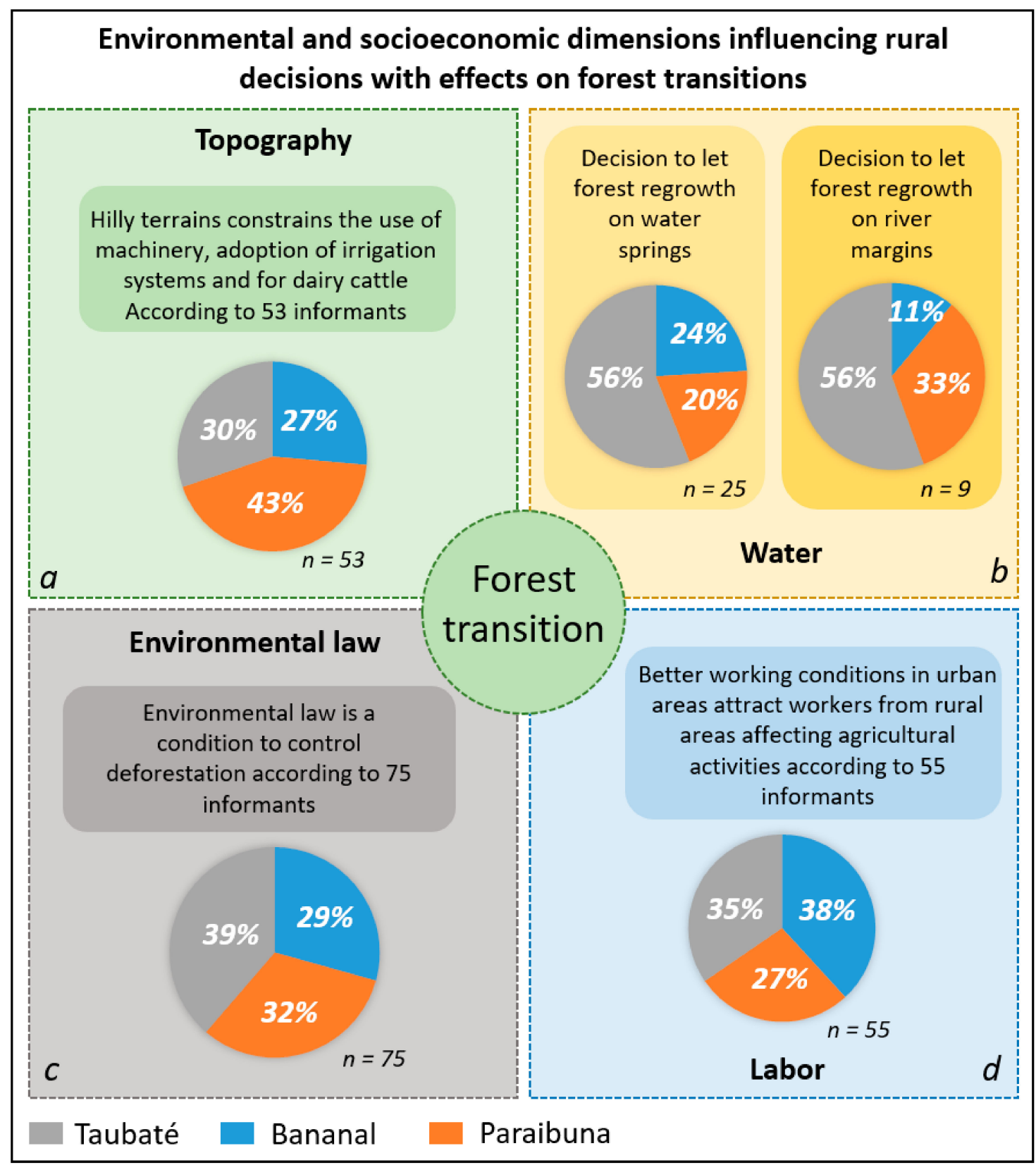

Figure 6. Decisions in rural properties are key to determine regional forest transitions ( $n$ is the number or respondents in each municipality according with variables $a, b, c$ or $d$ ).

In addition, based on a study in Rio de Janeiro State [13], due to their awareness about forests' role in maintaining water supplies, farmers are more prone to let forests grow around the springs than around river margins, although both of these areas should be preserved by law. Among the interviewees of rural properties with at least one agricultural activity, nine mentioned river margins whilst twenty-five indicated water springs as the less suitable areas for agricultural practices (Figure 6b). Between 1985 and 2011, 19\% of forest regeneration in Taubaté occurred over surface-water saturation zones (defined by the TWI approach), 21\% in Paraibuna, and 29\% in Bananal. These results indicated the absence of a strategic plan for forest restoration with a focus on water security during the observed period; otherwise, one would expect more forest increase over these areas as observed in steep slopes.

During 2013 and 2014, São Paulo State faced the worst recorded drought ever [37]. During 2014 , many properties faced water scarcity that compromised their rural activities. This scenario was influential to drive farmers' decision to adopt water conservation strategies. Two thirds of the 
interviewees recognized the forests' services to water production and maintenance. The observations made by Silvano et al. [13], and now by this study, exposes a potential pathway to forest regeneration following land-use decisions influenced by water concerns, and reinforced by the water crisis faced by farmers during 2013-2014; a subject that must be addressed by future remote sensing studies. A decline in the provision of ecosystem services clearly contributed to initiate FT as a socio-ecological feedback.

\subsection{The Interplay of Rural Population and Environmental Policy with the Forests}

Since the promulgation of the Brazilian constitution in 1988, society has been challenged to cope with a new paradigm on public policy management that promotes decentralization and participatory approaches [60]. In the Paraíba Valley, a set of behaviors is favoring compliance with environmental laws and the promotion of volunteer actions for ecosystem restoration [39].

Among the thirty-four rural properties that explore tourism as an economic activity or use the property for leisure, twenty-one $(61 \%)$ voluntarily reforested within the property. Tourism and leisure activities in rural areas have a greater likelihood of promoting environmental sustainability than agro-livestock, since these activities inherently value the recovery and conservation of natural environments in private lands [61].

Volunteer reforestation initiatives in the Paraíba Valley respond to environmental concerns and aesthetic values. Water conservation was the main concern that stimulated volunteer actions to restore natural forest areas in rural properties in Bananal and Paraibuna, whilst aesthetic values were also important in Taubaté.

Among the landowners who voluntarily established native forest plantations within the property, $12 \%$ had no formal education level, $7 \%$ basic education level, 33\% medium high school, and $46 \%$ undergraduate level education. The results suggested that the higher the level of formal education, the more likely the adoption of reforestation initiatives in the study region.

Previous research in the Paraíba Valley has identified a positive relationship between environmental policies, law enforcement, and individuals' action in deforestation control [37]. This study addressed scenarios for deforestation. Among the ninety interviewees, seventy-five (Figure $6 \mathrm{c}$ ) recognized environmental laws as a condition to control deforestation. Forty-five of them attributed compliance with the law to the active role of local people through environmental complaints filed with authorities. Based on an interviewee testimony, cell phones are the "best friends" of nature due to the fact that "everybody has one", even in rural areas; thus, every time that somebody sees some potential environmental crime they can call the Environmental Military Police (EMP) and file a report of a violation. In all municipalities, the way people act using these environmental complaints and responsiveness of the EMP were a condition to ensure control over new deforestation. The voluntary decision to respect the law was another option of the questionnaire to evaluate the control of deforestation, but it was not as important as the environmental complaint and EMP as a control.

All ninety interviewees affirmed that in the last three years they had not deforested any land. Some of them recognized deforestation actions in the past in their properties, but they were forced to repair the damages, according to environmental laws. Deforestation, suppression or exploitation of a natural vegetation without legal authorization is an environmental crime ( $\operatorname{Law~n}^{0} 11.428$ of 2006). Therefore, ensuring law enforcement by individuals actions in reporting crimes is a critical component to the forest governance in the Valley.

\subsection{The Fate of Rural Areas and the Regional Forest Transition}

Forest values encompass the maintenance of livelihoods, economic benefits, climate control, and several ecosystem services $[8,62,63]$. Landowners perception of ecosystem services depends on their own experiences and practices and they do not necessarily recognize the same services or forest benefits highly levered by scientists [13]. Rural practices such as land-use conversion, high-input (e.g., agrochemicals) production systems, non-tillage system, organic, and agroecological 
agricultural practices may affect the environmental quality, the provision of ecosystem services, and the conservation of natural resources. Future land-use and land-cover dynamics and human presence in rural areas (inducing agricultural and non-agricultural economic activities) will have consequences over forest cover areas, sometimes fostering FT, maintaining the forest areas stability or inducing new cycles of deforestation. We addressed two questions to assess the expectations about the future of rural areas in the three municipalities. The first question focused on the future expectations for regional agricultural activities (Table 5), and the second was about the future of rural populations and livelihoods (Table 6).

Table 5. Question addressed to interviewees about future expectations on agricultural activities in the Paraíba Valley, Brazil.

\begin{tabular}{cccc}
\hline $\begin{array}{c}\text { What Are the Future Expectations for Agricultural } \\
\text { Activities in the Paraíba Valley? }\end{array}$ & $\begin{array}{c}\text { Bananal } \\
(\mathbf{n} *)\end{array}$ & $\begin{array}{c}\text { Paraibuna } \\
(\mathbf{n} *)\end{array}$ & $\begin{array}{c}\text { Taubaté } \\
(\mathbf{n} *)\end{array}$ \\
\hline New agribusiness cycles & -- & 4 & 2 \\
Expansion of eucalyptus & -- & -- & -- \\
No changes & 9 & 12 & 8 \\
Organic/agroecological farms & 1 & 1 & -- \\
Cattle and dairy intensification & 2 & 4 & 7 \\
Loss of agricultural productivity & -- & -- & 3 \\
Increase of agricultural productivity & -- & -- & -- \\
Support from government rural extension agencies & -- & -- & 2 \\
Decrease of agricultural activities & 15 & 9 & 8 \\
Decrease of dairy but increase of cattle for beef & 3 & -- & -- \\
\hline *n equal to the number of respondents to each option (Total n equal third per municipality).
\end{tabular}

Table 6. Question addressed to interviewees about future expectations on rural livelihoods.

\begin{tabular}{cccc}
\hline $\begin{array}{c}\text { What Is the Future of Livelihoods and Population } \\
\text { in Rural Areas of the Paraíba Valley? }\end{array}$ & $\begin{array}{c}\text { Bananal } \\
(\mathbf{n} *)\end{array}$ & $\begin{array}{c}\text { Paraibuna } \\
\text { (n) }\end{array}$ & $\begin{array}{c}\text { Taubaté } \\
\text { (n) }\end{array}$ \\
\hline $\begin{array}{c}\text { Decline of rural population } \\
\text { No changes }\end{array}$ & 4 & 3 & 2 \\
$\begin{array}{c}\text { Increase of rural population } \\
\text { from non-agricultural activities }\end{array}$ & -- & -- & 1 \\
Increase of family farming & 17 & 26 & 26 \\
Increase of people living in rural areas with income & -- & 1 & 1 \\
\hline
\end{tabular}

${ }^{*} \mathrm{n}$ equal to the number of respondents to each option (Total $\mathrm{n}$ equal third per municipality).

Among the ninety interviewees (Table 5), thirty-two expected a decline of regional agricultural activities (e.g., diminished economic importance, or the number of agricultural activities), twenty-nine expected the maintenance of current practices with no changes and three expected decrease of rural productivity (i.e., productivity decline of the agricultural systems) - thus, sixty-four of them had no expectations of increasing rural economic activities in the municipalities. Only $28 \%$ of the interviewees had expectations of new rural cycles, the emergence of organic and agroecological production systems or the increase of current activities such as cattle for beef production. According to sixty-nine interviewees (Table 6), the rural population with jobs not related to rural activities or retired people will increase. From the interviewees perspective, the reasons of the urban to rural migrations may be motivated by expectations of economic advantages, since rural areas are less expensive than urban areas-affordability, and in some cases searching for a rural lifestyle or second home distant of urban areas-amenity migration [64]. These alternative modes of occupancy of rural areas may result in significant changes in land tenure, rural governance, and socioeconomic dynamics, fostering new cycles of regional environmental changes [65].

Low expectations about improvements in future rural activities, observed for both municipalities, reveals a scenario of continued low-scale family farming with the potential increase of new rural 
properties owned by urban dwellers searching for a residence in rural areas or for a second home, usually to enjoy contact with nature, grow plants, and raise animals. The expectations of decreasing agricultural activities (higher in Bananal, Table 5) is an indicator to predict more rural properties transitioning from agricultural practices to tourism and leisure activities, as expected by most of the respondents during the fieldwork (Table 6). The tendency of a property to become more dedicated for leisure or to be sold increases together with the financial difficulty to maintain the farm, aging of the owners, and difficulties in keeping family members from taking over the farm.

This transition dynamic will boost the increase of forest cover areas (FT) because of voluntary natural forest planting within rural properties dedicated for tourism and leisure. Moreover, if production areas are abandoned, they probably will undergo forest succession, the major process driving FT in the Paraiba Valley during the last 35 years [34].

Among the three municipalities, only two interviewees in Taubate expected improvements in rural technical assistance. As discussed in other studies [66-68], rural technical assistance is key to technology transfer, to support the adoption of the best land management practices and to allow rural economic development allied with environmental conservation. This result is alarming and should be a concern for policy-makers. Place-based policies must be designed for the region to promote and increase the capacity of rural technical assistance agencies to inform farmers' management practices [67].

With the exception of eucalyptus plantations, there is no other large-scale mechanized monocultural system in the Valley, currently. Eucalyptus plantations increased in the last three decades and according to the informants, there is no expectation of new eucalyptus plantation areas in private lands (Table 5). This result matches with the annual reports of the major pulp industries in the region. During 2012 and 2013, pulp production used only 1.43\% of eucalyptus from other rural properties; the other $98.57 \%$ came from the company's own lands [69] discouraging the expansion of eucalyptus in the Valley's rural properties. According to the company, the eucalyptus production in the Paraíba Valley is expensive compared with other regions in Brazil, due to the topography. Currently, eucalyptus expansion is taking place in new producer regions of Brazil with suitable topography for mechanization and reasonable land price. However, eucalyptus is still important for rural properties as a timber source for fences, barns, tools, firewood, and civil construction.

\section{Conclusions}

The regional forest cover changes in each municipality demonstrated that FT is taking place under different scenarios of forest cover area, presence of eucalyptus plantations, or urban economic development. This result highlights the existence of multiple pathways governing the regional FT in the Paraíba Valley.

We conclude that besides the importance of biophysical variables on land-use decision-making, socioeconomic changes affecting the region are influential in land-change processes. Additionally, a group of interviewees highlighted that the unevenness of urban job characteristics (e.g., higher wage, benefits such health insurance) compared to rural jobs undermine the workers choice of staying in rural areas (Figure 6d), leading the rural properties to face a shortage of young laborers and aging of the rural population. This context, influential in the decision of abandoning less suitable agricultural lands to FT, is one of the most fragile FT pathways, such as new cycles of economic changes boosting economic activities in rural areas, that would result in this process turning back. Therefore, the development and management of the rural landscapes in the Paraíba Valley must be done by rural-urban approaches, capable of promoting integrated rural-urban socioeconomic development to provide options to rural populations, and at the same time reinforcing the values of forest areas as building-blocks of the agricultural systems (e.g., providers of soil conservation, refuge for wildlife, such as pollinators and seed dispersers). This is key to maintain forest cover areas and to improve FT processes, for example towards sensible hydrological zones. 
Therefore, place-based policies [67] must be addressed in the region to stimulate the maintenance of the forest cover areas through payment of ecosystem services and stimulating rural and ecological tourism as economic ways to make profits in rural areas, whilst ensuring forest conservation. Policies and initiatives from the urban society can also stimulate the adoption of organic, agroforestry, and family farm systems in rural areas connected to local consumption markets, as a way to increase the social and cultural values of this traditional rural landscape, with potential positive effects on the environmental sustainability of the Valley. In addition, place-based policies must take into consideration the importance of educational level in rural populations as a means to reach more favorable attitudes toward forest conservation actions, as demonstrated by this research. The participatory role of rural society in supporting law enforcement to control deforestation must be strengthened through public investments in more effective communication systems connected to surveillance actions, which would result in more positive feedback from the rural population about the functioning of the forest governance system in the region.

The FT in the Valley occurred predominantly on less suitable agricultural lands, not on high value hydrologic zones important for water conservation, indicating that over the last decades the landowners were more prone to abandon lands with higher opportunity-costs than key areas for the provision and maintenance of ecosystem services. Future studies must address the question of: "Are droughts provoked by rainfall shortage driving afforestation in sensible hydrologic zones in order to restore ecosystem services?" Future satellite images covering the region will be suitable to capture the initial stages of forest succession and shed light on the role of extreme environmental events (e.g., drought) on land-use decisions in rural properties, as a socio-ecological feedback.

The deforestation control improved by the participatory process of local rural society, the low future expectations about agricultural activities in the Valley, and the growing number of people moving to rural areas looking for new lifestyles and amenity landscapes, challenges the future of this traditional farming landscape. Considering the endangered state of conservation of the Atlantic forest biome, this study brings attention to the importance of regional socioeconomic variables driving regional environmental changes and forest cover transition over time.

Author Contributions: R.F.B.d.S. led writing efforts, coordinated the literature review, fieldwork data collection, and edited the manuscript. M.B. and E.F.M. helped conceiving the manuscript, assisted with the literature review, and participated in editing of the article.

Funding: This research was funded by São Paulo Research Foundation (FAPESP), grant number 2011/13568-0 and 2013/09243-3.

Acknowledgments: We also acknowledge the help and support provided by the Center for Environmental Studies (NEPAM/UNICAMP), EMBRAPA (Brazilian Agricultural Research Corporation), and the Center for Global Change and Earth Observations (Michigan State University). The opinions expressed herein are the sole responsibility of the authors.

Conflicts of Interest: The authors declare no conflict of interest. The founding sponsors had no role in the design of the study; in the collection, analyses, or interpretation of data; in the writing of the manuscript, and in the decision to publish the results.

\section{References}

1. Goldewijk, K.K. Estimating global land use change over the past 300 years: The HYDE database. Glob. Geochem. Cycles 2001, 15, 417-433. [CrossRef]

2. Washington-Ottombre, C.; Pijanowski, B.; Campbell, D.; Olson, J.; Maitima, J.; Musili, A.; Kibaki, T.; Kaburu, H.; Hayombe, P.; Owango, E.; et al. Using a role-playing game to inform the development of land-use models for the study of a complex socio-ecological system. Agric. Syst. 2010, 103, 117-126. [CrossRef]

3. Post, W.M.; Kwon, K.C. Soil carbon sequestration and land-use change: Processes and potential. Glob. Chang. Biol. 2000, 6, 317-327. [CrossRef]

4. Wagner, P.D.; Kumar, S.; Schneider, K. An assessment of land use change impacts on the water resources of the Mula and Mutha Rivers catchment upstream of Pune, India. Hydrol. Earth Syst. Sci. 2013, 17, 2233-2246. [CrossRef] 
5. Pielke, R.A. Land Use and Climate Change. Science 2005, 310, 1625-1626. [CrossRef] [PubMed]

6. Foley, J.A.; Defries, R.; Asner, G.P.; Barford, C.; Bonan, G.; Carpenter, S.R.; Chapin, F.S.; Coe, M.T.; Daily, G.C.; Gibbs, H.K.; et al. Global consequences of land use. Science 2005, 309, 570-574. [CrossRef]

7. Lambin, E.F.; Meyfroidt, P. Land use transitions: Socio-ecological feedback versus socio-economic change. Land Use Policy 2010, 27, 108-118. [CrossRef]

8. Moran, E.F.; Ostrom, E. Seeing the Forest and the Trees: Human-Environment Interactions in Forest Ecosystems; MIT Press: Cambridge, UK, 2005.

9. Koontz, T.M. Money Talks? But to Whom? Financial Versus Nonmonetary Motivations in Land Use Decisions. Soc. Nat. Resour. Int. J. 2010, 14, 51-65.

10. Irwin, E.G.; Geoghegan, J. Theory, data, methods: Developing spatially explicit economic models of land use change. Agric. Ecosyst. Environ. 2001, 85, 7-23. [CrossRef]

11. Areal, F.J.; Riesgo, L. Farmers' views on the future of olive farming in Andalusia, Spain. Land Use Policy 2014, 36, 543-553. [CrossRef]

12. Beilin, R.; Lindborg, R.; Stenseke, M.; Pereira, H.M.; Llausas, A.; Slätmo, E.; Cerqueira, Y.; Navarro, L.; Rodrigues, P.; Reichelt, N.; et al. Analysing how drivers of agricultural land abandonment affect biodiversity and cultural landscapes using case studies from Scandinavia, Iberia and Oceania. Land Use Policy 2014, 36, 60-72. [CrossRef]

13. Silvano, R.A.M.; Udvardy, S.; Ceroni, M.; Farley, J. An ecological integrity assessment of a Brazilian Atlantic Forest watershed based on surveys of stream health and local farmers' perceptions: Implications for management. Ecol. Econ. 2005, 53, 369-385. [CrossRef]

14. Panthi, J.; Aryal, S.; Dahal, P.; Bhandari, P.; Krakauer, N.Y.; Pandey, V.P. Livelihood vulnerability approach to assessing Climate change impacts on mixed agro-livestock smallholders around the Gandaki River Basin in Nepal. Reg. Environ. Chang. 2016, 16, 1121-1132. [CrossRef]

15. Mango, N.; Makate, C.; Tamene, L.; Mponela, P.; Ndengu, G. Adoption of small-scale irrigation farming as a climate-smart agriculture practice and its influence on household income in the Chinyanja Triangle, Southern Africa. Land 2018, 7, 49. [CrossRef]

16. Ango, T.G.; Borjeson, L.; Senbeta, F.; Hylander, K. Balancing Ecosystem Services and Disservices: Smallholder Farmers' Use and Management of Forest and Trees in an Agricultural Landscape in Southwestern Ethiopia. Ecol. Soc. 2014, 19, 30. [CrossRef]

17. Gurri, F.D. Smallholder land use in the southern Yucatan: How culture and history matter. Reg. Environ. Chang. 2010, 10, 219-231. [CrossRef]

18. Ojha, H.R.; Shrestha, K.K.; Subedi, Y.R.; Shah, R.; Nuberg, I.; Heyojoo, B.; Cedamon, E.; Rigg, J.; Tamang, S.; Paudel, K.P.; et al. Agricultural land underutilization in the hill of Nepal: Investigating socio-environmental pathways of change. J. Rural Stud. 2017, 53, 156-172. [CrossRef]

19. Ngutu, M.; Bukachi, S.; Olungah, C.O.; Kiteme, B.; Kaeser, F.; Haller, T. The actors, rules and regulations linked to export horticulture production and access to land and water as common pool resources in Laikipia County, Northwest Mount Kenya. Land 2018, 7, 110. [CrossRef]

20. Rudel, T.K.; Coomesb, O.T.; Moran, E.; Achardd, F.; Angelsene, A.; Xuf, J.; Lambin, E. Forest transitions: Towards a global understanding of land use change. Glob. Environ. Chang. 2005, 15, 23-31. [CrossRef]

21. Chazdon, R. Tropical Forest Regeneration. Bol. Mus. Pará. Emílio Goeldi Cienc. Nat. 2012, 7, 195-218.

22. Gray, C.L.; Bilsborrow, R.E. Consequences of out-migration for land use in rural Ecuador. Land Use Policy 2014, 36, 182-191. [CrossRef] [PubMed]

23. He, J.; Lang, R.; Xu, J. Local Dynamics Driving Forest Transition: Insights from Upland Villages in Southwest China. Forests 2014, 5, 214-233. [CrossRef]

24. Ferreira, M.P.; Alves, D.S.; Shimabukuro, Y.E. Forest dynamics and land-use transitions in the Brazilian Atlantic Forest: The case of the sugarcane expansion. Reg. Environ. Chang. 2015, 15, 365-377. [CrossRef]

25. Silva, R.F.B.; Batistella, M.; Moran, E.F. Drivers of land change: Human-environment interactions and the Atlantic forest transition in the Paraíba Valley, Brazil. Land Use Policy 2016, 58, 133-144. [CrossRef]

26. Loran, C.; Ginzler, C.; Bürgi, M. Evaluating forest transition based on a multi-scale approach: Forest are dynamics in Switzerland 1850-2000. Reg. Environ. Chang. 2016, 16, 1807-1818. [CrossRef]

27. McConnell, W.J.; Viña, A.; Kull, C.; Batko, C. Forest transitions in Madagascar's highlands: Initial evidence and implications. Land 2015, 4, 1155-1181. [CrossRef] 
28. Tucker, C.M.; Southworth, J. Processes of Forest Change at the Local and Landscape Levels in Honduras and Guatemala. In Seeing the Forest and the Trees: Human-Environment Interactions in Forest Ecosystems; Moran, E.F., Ostrom, E., Eds.; MIT Press: Cambridge, UK, 2005; pp. 253-277.

29. Tabarelli, M.; Pinto, L.P.; Silva, J.M.C.; Hirota, M.M.; Bedê, L.C. Challenges and opportunities for biodiversity conservation in the Brazilian Atlantic Forest. Megadiversidade 2005, 1, 132-138. [CrossRef]

30. Victor, M.A.M.; Cavalli, A.C.; Guillaumon, J.R.; Serra Filho, R. One Hundred Years of Devastation Reviewed Thirty Years After; MMA: Brasília, Brazil, 2005. (In Portuguese)

31. Lira, P.K.; Tambosi, L.R.; Ewers, R.M.; Metzger, J.P. Land-use and land-cover change in Atlantic Forest landscapes. For. Ecol. Manag. 2012, 15, 80-89. [CrossRef]

32. SOS Mata Atlântica, Fundação/INPE. Atlas of the Atlantic Forest Remnants in the Period of 2012-2013; Fundação SOS Mata Atlântica/INPE: São Paulo, Brazil, 2014. (In Portuguese)

33. Borgonovi, M.; Chiarini, J.V.; Amaral, A.Z.; Coelho, G.S.; Oliveira, D.A. Cobertura Vegetal do Estado de São Paulo. Bragantia 1967, 26, 95-102. [CrossRef]

34. Silva, R.F.B.; Batistella, M.; Moran, E.F.; Lu, D. Land Changes Fostering Atlantic Forest Transition in Brazil: Evidences from the Paraíba Valley. Prof. Geogr. 2017, 69, 80-93. [CrossRef]

35. Farinaci, J.S.; Batistella, M. Variation on native vegetation cover in São Paulo: An overview of current knowledge. Revista Árvore 2012, 36, 695-705. [CrossRef]

36. Itani, M.R.; Barros, C.M.; Figueiredo, F.E.L.; Andrade, M.R.M.; Mansor, M.T.C.; Mangabeira, R.L.; Carvalho, V.S. Environmental Planning: Unit of Water Resources Management of Paraíba do Sul; SAM: São Paulo, Brazil, 2011. (In Portuguese)

37. Soriano, E.; Londe, L.R.; Gregorio, L.T.D.; Coutinho, M.P.; Santos, L.B.L. Water crisis in São Paulo evaluated under the disaster's point of view. Ambient. Soc. 2016, 19, 21-42. [CrossRef]

38. Funcate. GHG Emissions from Land Use, Land-Use Change, and Forestry Sector in São Paulo State; CETESB: São Paulo, Brazil, 2012.

39. Silva, R.F.B.; Batistella, M.; Moran, E.F. Socioeconomic changes and environmental policies as dimensions of regional land transitions in the Atlantic Forest, Brazil. Environ. Sci. Policy 2017, 74, 14-22. [CrossRef]

40. Aggarwal, C.C. Outlier Analysis; Springer: New York, NY, USA, 2013.

41. Minella, J.P.G.; Merten, G.H. Topographic Index applied to Agricultural and Environmental Modelling. Ciênc. Rural 2012, 42, 1575-1582. [CrossRef]

42. Silva, R.F.B.; Ferraz, S.F.B.; Sartori, A.A.C.; Zimback, C.R.L. Integration of hydrologic processes for zoning agricultural landscapes: Perspectives for ecosystem services maintenance. J. Environ. Sci. Water Resour. 2013, 2, 290-301.

43. Beven, K.J.; Kirkby, M.J. A physically based, variable contributing area model of catchment hydrology. Hydrol. Sci.-Bull. 1979, 24, 43-69. [CrossRef]

44. Sorensen, R.; Zinko, U.; Seibert, J. On the calculation of the topographic wetness index: Evaluation of different methods based on field observations. Hydrol. Earth Syst. Sci. Discuss. 2005, 2, 1807-1834. [CrossRef]

45. Oliveira, M.V.M.; Teixeira, M.M.; Fernandes, H.C.; Silva, A.C.; Furtado Júnior, M.R. Evaluation Lateral Stability of a Coffee Harvester for Mountain Regions Using Computer Programs; VIII Simpósio de Pesquisa dos Cafés do Brasil: Salvador, Brazil, 2013.

46. Oliveira, J.S.; Zocoler, J.L. Bean cost of irrigation and profit in a center pivot system under variation of pressurized pipe length and topographic levels. Eng. Agric. 2013, 33, 121-128.

47. Berge, R.D.; Carter, D.L. Furrow erosion and sediment losses on irrigated cropland. J. Soil Water Conserv. 1980, 35, 267-270.

48. Stotz, E.N. Limits of conventional agriculture and reasons for its persistence: A case study in Sumidouro, Rio de Janeiro. Braz. Rev. Bras. Saúde Ocup. 2012, 37, 114-126. [CrossRef]

49. Silveira, J.M. Brazilian agriculture: The role of technological innovation. In The Rural World in Brazil in the 21th Century; Buainain, A.M., Alves, E., Silveira, J.M., Navarro, Z., Eds.; EMBRAPA: Brasília, Brazil, 2014; pp. 373-394. (In Portuguese)

50. Garcia, J.R. Rural labor: Trends of changes. In The Rural World in Brazil in the 21th Century; Buainain, A.M., Alves, E., Silveira, J.M., Navarro, Z., Eds.; EMBRAPA: Brasília, Brazil, 2014; pp. 559-590. (In Portuguese)

51. Cramer, V.A.; Hobbs, R.J.; Standish, R.J. What's new about old fields? Land abandonment and ecosystem assembly. Trends Ecol. Evol. 2008, 23, 104-112. [CrossRef] [PubMed] 
52. Vieira Filho, J.E.R. Historical changes and technological standards in the Brazilian agriculture. In The Rural World in Brazil in the 21th Century; Buainain, A.M., Alves, E., Silveira, J.M., Navarro, Z., Eds.; EMBRAPA: Brasília, Brazil, 2014; pp. 395-422. (In Portuguese)

53. IBGE (Instituto Brasileiro de Geografia e Estatística). Censo Demográfico 2010; IBGE: Rio de Janeiro, Brazil, 2010.

54. Vieira, E.T.; Santos, M.J. Industrialization and regional development: CODIVAP policy in the Paraíba Valley in the 1970s. Desenvolv. Reg. Debate 2012, 2, 161-181.

55. Helfand, S.M.; Pereira, V.F.; Soares, W. Medium and small farmers in the Brazilian agriculture: Current situation and future perspectives. In The Rural World in Brazil in the 21th Century; Buainain, A.M., Alves, E., Silveira, J.M., Navarro, Z., Eds.; EMBRAPA: Brasília, Brazil, 2014; pp. 533-558. (In Portuguese)

56. Ab'Saber, A.N. Os Domínios de Natureza no Brasil: Potencialidades Paisagísticas, 6th ed.; Ateliê Editorial: São Paulo, Brazil, 2003.

57. Buainain, A.M.; Alves, E.; Silveira, J.M.; Navarro, Z. The Rural World in Brazil in the 21th Century; EMBRAPA: Brasília, Brazil, 2014. (In Portuguese)

58. Dean, W. A Ferro e Fogo: História de Uso e Ocupação da Mata Atlântica; Cia. das Letras: São Paulo, Brazil, 1996.

59. Lepsch, I.F.; Bellinazzi, R., Jr.; Bertolini, D.; Espíndola, R. Manual for Utility Survey of the Physical Environment and Land Classification by the System of Land Use Capacity, 4th ed.; Brazilian Society of Soil Science: Campinas, Brazil, 1991.

60. Carvalho, P.G.; Oliveira, S.M.M.C.; Barcellos, F.C.; Assis, J.M. Gestão Local e Meio Ambiente. Ambient. Soc. 2005, 8, 121-140. [CrossRef]

61. Roque, A. Estudo Preliminar da Cadeia Produtiva: Turismo Rural no Brasil; IICA Brasil: Brasília, Brazil, 2013.

62. Azevedo, J.C.; Pereira, A.H.; Pinto, M.A. Forest Landscapes and Global Change: Challenges for Research and Management; Springer: New York, NY, USA; Heidelberg/Berlin, Germany; Dordrecht, The Netherlands; London, UK, 2014.

63. Fenning, T. Challenges and Opportunities for the World's Forest in the 21st Century; Springer: Edinburgh, UK, 2014.

64. Argent, N.; Tonts, M.; Jones, R.; Holmes, J. The amenity principle, internal migration, and rural development in Australia. Ann. Assoc. Am. Geogr. 2014, 104, 305-318. [CrossRef]

65. Holmes, J.; Argent, N. Rural transitions in the Nambuca Valley: Socio-demographic change in a disadvantaged rural locale. J. Rural Stud. 2016, 48, 129-142. [CrossRef]

66. Landini, F. How to be a good rural extensionists. Reflections and contributions of Argentine practitioners. J. Rural Stud. 2016, 43, 193-202. [CrossRef]

67. Silva, R.F.B.; Rodrigues, M.DA.; Vieira, S.A.; Batistella, M.; Farinaci, J. Perspectives for environmental conservation and ecosystem services on coupled rural-urban systems. Perspect. Ecol. Conserv. 2017, 15, 74-81. [CrossRef]

68. Latawiec, A.E.; Strassburg, B.B.N.; Silva, D.; Alves-Pinto, H.N.; Feltran-Barbieri, R.; Castro, A.; Iribarrem, A.; Rangel, M.; Kalif, K.; Gardner, T.; et al. Improving land management in Brazil: The producers' perspective. Agric. Ecosyst. Environ. 2017, 240, 276-286. [CrossRef]

69. Fibria. Relatório de Sustentabilidade 2013; Fibria: São Paulo, Brazil, 2014.

(C) 2018 by the authors. Licensee MDPI, Basel, Switzerland. This article is an open access article distributed under the terms and conditions of the Creative Commons Attribution (CC BY) license (http:// creativecommons.org/licenses/by/4.0/). 